\title{
Penerapan Pendidikan Humanis Demokratis di Sekolah Dasar Eksperimental Mangunan
}

\author{
Anatoli Kasparov Putuabdullah ${ }^{1}$, Sunarso ${ }^{2}$ \\ Pasca Sarjana Pendidikan Kewarganegaraan, Universitas Negeri Yogyakarta ${ }^{1,2}$ \\ Email: abdullahanatoly@gmail.com ${ }^{1^{*}}$ \\ *corresponding author
}

\begin{abstract}
Abstrak
Artikel ini bertujuan untuk mengetahui penerapan pendidikan humanis demokratis di SD Eksperimental Mangunan. Dilatarbelakangi situasi pendidikan saat ini yang cenderung berpusat pada guru, sehingga menjadikan siswa sebagai objek yang pasif. Artikel ini merupakan penelitan studi kasus dengan menggunakan pendekatan kualitatif yang dilakukan di Sekolah Dasar Eksperimental Mangunan Yogyakarta pada Juli-Agustus tahun 2021. Data penelitian dikumpulkan dengan menggunakan teknik wawancara dan dokumentasi. Pemeriksaan keabsahan data mengunakan teknik triangulasi sumber dan teknik. Sedangkan teknik analisis data menggunakan teknik analisis kualitatif Miles dan Huberman, dengan tahap: (1) mereduksi data yang diperoleh, (2) menyajikan data dengan teks naratif dan gambar, (3) melakukan penarikan kesimpulan dan verifikasi. Kesimpulan penelitian ini adalah SD Eksperimental Mangunan telah menerapkan pembelajaran humanis demokratis Mangunwijaya, yang ditandai dengan anggapan bahwa setiap anak memiliki tujuh modal dasar yang harus dimekarkan dengan berbagai program, pembelajaran yang memerdekakan anak melalui kegiatan koper (kotak pertanyaan) dan nggiwar (berfikir tidak linier), pembelajaran yang bermakna dengan menjadikan masyarakat sebagai sekolah dan sekolah sebagai masyarakat, model pembelajaran menggunakan project based learning yang mendorong siswa untuk aktif bereksploratif dan berkreasi guna menemukan pengetahuannya sendiri.
\end{abstract}

Kata kunci : pendidikan humanis; demokrasi pendidikan; SD Eksperimental Mangunan, Mangunwijaya.

\section{Application of Democratic Humanist Education in Mangunan Experimental Elementary School}

\begin{abstract}
This study aims to determine the application of democratic humanist education at the Mangunan Experimental Elementary School. The background of the current educational situation tends to be teacher-centered, thus making students passive objects. This research is a case study research using a qualitative approach. The research was conducted at the Mangunan Experimental Elementary School, Yogyakarta in July-August 2021. The research data was collected using interview and documentation techniques, checking the validity of the data using triangulation of sources and techniques. While the data analysis technique used the qualitative analysis technique of Miles and Huberman, with the stages: (1) reducing the data obtained, (2) presenting the data with narrative text and pictures, (3) drawing conclusions and verification. The conclusion of this research is that at the Mangunan Experimental Elementary School, Mangunwijaya democratic humanist learning has been applied, which is characterized by the
\end{abstract}


assumption that every child has seven basic capitals that must be expanded with various programs, learning that liberates children through briefcase activities (question boxes) and nggiwar (nonlinear thinking), meaningful learning by making the community as a school and the school as a community, a learning model using project based learning that encourages students to actively explore and be creative in order to find their own knowledge.

Keywords : humanistic education; democratic education; mangunan experimental elementary school; Mangunwijaya.

\section{LATAR BELAKANG}

Kajian ini akan memotret bagaimana pendidikan yang humanis diterapkan ke dalam institusi pendidikan yaitu di Sekolah Dasar Eksperimental Mangunan. Berangkat dari asumsi bahwa dalam diri manusia memiliki potensi-potensi yang baik sehingga institusi sekolah hendaknya memberi ruang bagi siswa untuk mengembangkan potensipotensi yang dimilikinya. Namun praktek dilapangan secara umum, proses pendidikan yang berlangsung di sekolah-sekolah masih cenderung bergaya behavioristik dan kurang humanis serta demokratis. Hal tersebut terjadi karena dalam proses pembelajaran behaviorisktik siswa ditempatkan hanya sebagai objek, sedangkan guru merupakan subjeknya (teacher oriented). Siswa hanya merespon jika diberi stimulus oleh guru, akibatnya siswa tidak terbiasa untuk menemukan pengetahuan sendiri. Relasi guru dan murid semacam ini jika berlangsung terus menerus akan membentuk hubungan yang cenderung dogmatik. Dampaknya siswa-siswa tidak terlatih untuk bisa mengaktualisasikan potensi-potensi yang ada dalam dirinya.

Bacaan atas fenomena tersebut nampak jelas dari tulisan Freire yang menemukan fakta tentang proses pembelajaran yang cenderung "bergaya bank". Pembelajaran ini memposisikan siswa sebagai tempat penyimpanan, sedangkan guru adalah depositor. Siswa hanya memiliki kesempatan menjadi kolektor atau cataloguers (Freire, 1999). Sedangkan dari persepektif sosiologi pendidikan, Foucault memandang bahwa sebagian besar proses pendidikan di sekolah secara metafor identik dengan penjara. Kalau penjara dijadikan sebagai tempat untuk melakukan pendisiplinan terhadap individu dengan berbagai pengawasan, hukuman, serta pembiasaan. Maka sekolah tidak jauh berbeda dari akitivitas-aktivitas tersebut. Jika di dalam penjara terdapat berbagai jadwal dan rutinitas setiap hari yang harus dilakukan seperti masuk ke dalam sel saat bel berbunyi, dan di dalam penjara terdapat berbagai jadwal yang mesti dikuti oleh para narapinda. Hal tersebut juga terjadi di sekolah, aktivitas dimulai dengan bel masuk kelas, dan di dalam sekolah juga terdapat berbagai bentuk kegiatan sebagai cara pendisiplinan siswa (Foucault, 1999)

Telaah mengenai pendidikan yang bernuansa tidak demoktratis dan tidak humanis dalam konteks Indonesia juga dilakukan oleh Mansour Fakih (2010) dan Darmaningtiyas (2012). Mereka menemukan benang merah teoritik yang sama dengan Freire, dan Foucault, yaitu pendidikan di Indonesia cenderung berpola behavioristik dari pada humanistik. Secara umum, proses pembelajaran berlangsung indoktrinatif dimana siswa dijadikan sebagai objek dalam proses belajar. Siswa dikondisikan dan didisiplinkan sedemikian rupa untuk menyesuaikan kepentingan rezim dan kebutuhan kapitalisme. Kondisi tersebut nampak dari bagaimana proses doktrinasi pendidikan dizaman orde baru terkait penanaman nilai-nilai Pancasila (P4), siswa dikondisikan untuk wajib menghafal dan melaksanakan nilai-nilai $P 4$, namun alpa terhadap 
pendidikan terkait hak warga negara serta bagaimana cara memperjuangkan hak tersebut (Darmaningtiyas, 2012).

Kritik yang lebih tajam terhadap sistem pendidikan Indonesia juga disuarakan oleh Romo Wahono, bahwa sistem pendidikan yang diterapkan di Indonesia bermodel anjing. Model pendidikan yang hanya bersifat menghafal, memproduksi kepatuhan, sistem komando, mensubordinasi dan menerapkan sistem sentralistik. Model pendidikan yang baik hendaknya sebagaimana ayam yang mengajarkan realitas kehidupan kepada anak-anaknya. Induk ayam membiarkan anak-anaknya mencari makan sendiri sedangkan dirinya hanya mengawasi. Pola ini menuntut para guru sebagaimana rekan atau sahabat bermain dan bukan sebagai komandan. Bukan sosok yang sekedar ditakuti namun menjadi mitra yang dicintai. Kebenaran bukan berpusat pada guru namun ditemukan dengan mencarinya secara bersama-sama (Susetyo, 2005).

Sedikit berbeda dengan beberapa kritikus pendidikan di atas yang cenderung menyoroti situasi pendidikan Indonesia dari sisi paradigmatik. Penelitian yang dilakukan oleh Al-Hamdi (2017), Hadi et al. (2016), Munirah (2015), dan Perdana (2013, p. 67-63), lebih melihat pada tataran praksis di lapangan. Perbedaan cara pandang justru memperkuat tesis tentang pendidikan di Indonesia yang bercorak kurang humnanis dan demokratis. Sebagaimana Hamdi yang mengamati aktivitas pembelajaran di sekolah, telah mengkonfirmasi teori Foucault tentang sekolah adalah penjara. Kesimpulan tersebut tampak dari adanya kebijakan seragamisasi dan penyamarataan terhadap siswa dengan mengatasnamakan kebersamaan. Siswa yang belajar di sekolah se Indonesia diwajibkan menyelesaikan seluruh kurikulum yang sama. Sehingga terlalu banyak mata pelajaran yang mesti diselesaikan dan dipelajari, terkadang beban belajar tersebut melebihi waktu yang tersedia hingga membuat siswa menjadi stress. Dengan beban kurikulum yang banyak, guru justru terfokus untuk mengejar terselesainya kurikulum daripada memastikan apakah potensi siswa berkembang selama mengikuti pembelajaran (Al-Hamdi, 2017).

Penyamarataan dalam hal evaluasi belajar juga terjadi dengan adanya UN (Ujian Nasional). Dengan Ujian Nasional (UN) maka kriteria keluluasan siswa distandarisasi secara nasional. Evaluasi belajar dengan cara Ujian Nasional (UN) menurut Hadi justru tidak dibutuhkan dengan alasan yang mengerti peserta didik adalah guru. Evaluasi belajar tidak bisa hanya ditentukan selama tiga hari dengan mengerjakan soal-soal yang ada didalam Ujian Nasional. Hal ini justru meniadakan penilian pada proses dan hanya mementingkan hasil semata. Keberhasilan anak hanya dilihat dari nilai hasil ujian semata, jika tidak lulus maka anak akan dicap sebagai anak bodoh, dampaknya siswa menjadi minder. Akibatnya justru mematikan potensi-potensi siswa yang lain, karena hanya fokus pada satu jenis potensi saja dan mengabaikan terhadap pengembangan potensi-potensi lainya (Hadi et al., 2016).

Tujuan pendidikan sebagai tempat untuk mengembangkan potensi anak didik agar menjadi manusia yang beriman dan bertakwa kepada Tuhan Yang Maha Esa, berakhlak mulia, sehat, berilmu, cakap, kreatif, mandiri, dan menjadi warga negara yang demokratis serta bertanggung jawab justru diwujudkan dengan desain sistem pendidikan yang kurang humanis dan demokratis. Pengelolaan pendidikan cenderung dikelola secara sentralistik berlaku diseluruh tanah air baik berupa tujuan pendidikan, materi ajar, metode pembelajaran, buku ajar, tenaga kependidikan, siswa, guru maupun 
karyawan, mengenai syarat penerimaanya semuanya diatur oleh pemerintah dan berlaku untuk di seluruh pelosok tanah air (Munirah, 2015).

Pendidikan yang bercorak humanis tidak lepas dari filsafat humanisme. Pokok pikiran dari filsafat humanisme adalah memposisikan manusia sebagai subjek yang merdeka, berhak menentukan segala perilakunya sendiri. Semangat humanisme sebenarnya sudah ada semenjak Yunani klasik yang ditandai dengan adanya sistem pendidikan yang memerdekakan manusia yang disebut paideia, yaitu sistem pendidikan yang mengupayakan pembentukan manusia ideal. Manusia ideal dalam perspektif Yunani klasik merupakan manusia yang mengalami keselarasan jiwa dan badan, kondisi dimana manusia mencapai kebahagiaan. Kurikulum tradisional Yunani klasik dikenal dengan artes liberals atau liberal arts (pendidikan untuk orang-orang merdeka). Kurikulum tersebut terdapat tujuh bidang pelajaran yang diajarkan dalam rangka mencapai arete (keutamaan atau kebajikan). Ketujuh mata pelajaran tersebut yaitu tata bahasa, kemampuan berbicara (retorika), logika, berhitung (matematika), geometri (ilmu ukur), astronomi, dan musik (Samho, 2013: 25-28).

Pendidikan humanis diawali dari konsep psikologi humanistik Maslow yang memandang sifat manusia secara kodrati memiliki potensi-potensi sifat kebaikan yang perlu diaktualisasikan (Graham, 2005). Maslow beranggapan bahwa motivasi perilaku manusia didasari pada lima kebutuhan dasar yang dikenal dengan teori hierarki kebutuhan. Kelima kebutuhan dasar tersebut antara lain, kebutuhan fisiologis (physilogical needs), kebutuhan akan rasa aman (safety needs), kebutuhan untuk diterima (social needs), kebutuhan untuk dihargai (self esteem needs), kebutuhan aktualisasi diri (self actualization) (Aruma \& Enwuvesi Hanachor, 2017).

Sedangkan menurut Freire, pendidikan humanis sebagai cara memanusiakan manusia serta membebaskan manusia dari penindasan. Konsep pendidikan yang menindas atau bergaya bank memiliki ciri sebagai berikut: 1) Guru mengajar dan murid diajarkan. 2) Guru mengetahui segala sesuatu sedangka murid tidak tahu apa-apa. 3) Guru berfikir lalu murid dipikirkan. 4) Guru bercerita, murid penuh mendengarkan. 5) Guru membuat dan menentukan peraturan, siswa diatur. 5) Guru memilih dan memaksakan pilihannya, murid menyetujui. 6) Guru berbuat lalu murid membayangkan dirinya berbuat melalui perbuatan gurunya. 7) Guru memilih dan bahan dan isi pelajaran, murid tanpa diminta pendapatnya menyesuaikan diri dengan pelajaran itu. 8) Guru mencampuradukan kewenangan ilmu pengetahuan dan kewenangan jabatanya, yang dia lakukan untuk menghalangi kebebasan murid. 9) Guru adalah subjek dalam proses belajar dan murid adalah objek belaka (Freire, 1999).

Sedangkan pendidikan humanis Dewey menganggap manusia memiliki potensipotensi yang bisa tumbuh dan berkembang, namun poses memanusiakan manusia atau aktualisasi potensi yang ada dalam diri manusia tidak secara taken of granted terbentuk, dibutuhkan lingkungan yang demokratis untuk bisa mendorong agar potensi-potensi dalam diri manusia bisa teraktualisasikan (Samawi, 1995). Dalam suasana demokratis tersebut masyarakat tidak terikat oleh dogma, karena masyarakat berhak mencari sarana dalam memecahkan masalah yang muncul secara merdeka.

Suatu pengetahuan atau nilai disetujui melalui diskusi terbuka berdasarkan pada bukti yang faktual dan logis, bukan dipaksakan oleh pihak tertentu. Pengetahuan dan nilai muncul dari keinginan dan dorongan, sebagai perbaduan antara faktor psikologis dan sosial dirinya, untuk itu suasana yang demokratis diperlukan supaya memberi ruang bagi munculnya pengetahuan yang baru. Pendidikan merupakan upaya membantu 
manusia supaya mampu berefleksi terhadap masalah yang terjadi dalam masyarakat dan upaya memperlengkapi mereka agar menghasilkan perubahan yang nyata dalam kehidupan. Demokrasi pendidikan menurut Dewey adalah suatu pandangan, sikap dan aktivitas yang memberi ruang dan kesempatan sebesar-besarnya kepada siswa-siswa untuk berpartisipasi dalam menentukan pendidikannya supaya dapat tumbuh dan berkembang secara optimal dan wajar sesuai potensi-potensi yang ada dalam dirinya (Maiaweng, 2009).

Dalam konteks Indonesia, penelitian pendidikan humanis sudah banyak dilakukan, terutama tentang pendidikan humanis yang bercorak agama. Sebagaimana tulisan Adam (2015) yang berjudul Pendidikan Humanis Dalam Perspektif Islam (Konsep Dan Implementasinya Dalam Proses Belajar Mengajar) dan juga tulisan Idris \& Tabrani (2015) yang berjudul Realitas Konsep Pendidikan Humanisme Dalam Konteks Pendidikan Islam. Kedua tulisan tersebut lebih menekan bagaimana pendidikan humanis Islam diterapkan disekolah. Sedangkan penelitian ini lebih menekankan pada mencari kekhasan dari pendidikan humanis yang diterapkan di suatu sekolah, yaitu SD Eksperimental Mangunan.

Persoalan-persoalan terkait pendidikan yang kurang humanis sebagaimana telah diutarakan di atas dijawab oleh Mangunwijaya dengan merintis sekolah model humanis bernama Sekolah Dasar Eksperimental (SDE). Menurut Magunwijaya, pendidikan dan sekolah hendaknya membantu siswa untuk mengenali potensi-potensi dirinya dan mampu mengaktualisasikan potensi-potensi yang dimiliknya hingga menjadi manusia yang mandiri, dewasa, dan merdeka. (Mangunwijaya, 2004)

Pendidikan yang diusahakan Mangunwijaya menggunakan pendekatan pendagogi yang humanis (Indriatno, 2009). Metode pembelajaran yang diterapkan menggunakan konstruksif-progresif yakni metode pembelajaran yang membantu peserta didik melakukan kegiatan tertentu dan pada akhirnya peserta didik mampu mencipta atau mengkontruksi pengetahuan dari apa yang mereka kerjakan. Pendagogi mengajar Mangunwijaya yaitu siswa dan guru memiliki hubungan yang cenderung dialogis dan saling mengisi diantara keduanya (Indriatno, 2009). Penggunaan model pembelajaran yang cenderung anti mainstream ini membuat Sekolah Dasar Eksperimental Mangunan menarik untuk dikaji lebih mendalam. Maka dari itu penelitian ini akan mengkaji mengenai penerapan pendidikan humanis demokratis di SD Eksperimental Mangunan.

\section{METODE PENELITIAN}

Artikel berbasis penelitian ini menggunakan pendekatan kualitatif dengan jenis penelitian studi kasus. Pendekatan ini digunakan sebagai upaya menemukan kekhasan model pembelajaran humanis yang diterapkan di SD Eksperimental Mangunan yang mana waktu penelitian dilakukan pada bulan Juli-Agustus 2021. Subyek penelitian adalah orang yang memiliki kewenangan membuat kebijakan dan pelaksana kebijakan di SD Eksperimental Mangunan seperti Kepala kantor Yayasan Dinamika Edukasi Dasar, Kepala SD Eksperimental Mangunan, dan Guru SD Eksperimental Mangunan Yogyakarta.

Teknik pengumpulan data dalam penelitian ini adalah dengan melakukan wawancara kepada Kepala kantor Dinamikan Eduakasi Dasar dan Kepala Sekolah SD. Analisa dokumen, berupa rekaman video kegiatan yang diupload di chanel youtube resmi SD Eksperimental Mangunan, dan juga analisis terhadap dokumen berupa tulisan, artikel 
terkait dengan pemikiran Y.B. Mangunwijaya dan proses pendidikan juga dilakukan. Wawancara dilakukan kepada Kepala Sekolah SD Eksperimntal Mangunan dan Kepala Kantor Dinamika Edukasi Dasar (DED). Keabsahan data diperiksa dengan triangulasi sumber dan teknik, yaitu dengan mengkroscek antara narasumber satu dengan narasumber lainnya, atau antara narasumber dengan dokumen yang ada. Sedangkan teknik analisis data menggunakan teknik analisis kualitatif Miles dan Huberman, dengan tahap: (1) mereduksi data yang diperoleh yaitu memilah hasil wawancara dan dokumen yang berhubungan dengan pendidikan humanis di SD Eksperimental Mangunan, (2) menyajikan data dengan teks naratif dan gambar tentang penerapan pendidikan humanis di SD Eksperimetal Mangunan, (3) melakukan penarikan kesimpulan dan verifikasi dari data-data yang ada terkait bagaimana penerapan pendidikan humanis di SD Eksperimental Mangunan.

\section{HASIL DAN PEMBAHASAN}

Berdirinya Sekolah Dasar berawal dari kritik atas kondisi pendidikan Indonesia yang yang dianggap kurang memerdekakan siswa. Dari kegelisahan tersebut, Y.B. Mangunwijaya berinisiatif untuk mendirikan Yayasan Dinamika Edukasi Dasar (DED) untuk mewujudkan pendidikan yang Humanis. Yayasan Dinamika Edukasi Dasar (DED) milik Yayasan Kanisius yang terletak di desa Mangunan menjadi tempat bagi Y.B. Mangunwijaya dan Dinamika Edukasi Dasar (DED) sebagai laboratorium uji coba atas konsep pendidikan yang humanis. Sebenarnya SD Kanisius Mangunan sudah hampir ditutup karena memiliki kendala keuangan. Pada saat itu, direktur Yayasan Kanisius sepakat atas rencana yang di sampaikan oleh Y.B. Mangunwijaya. Selanjutnya sekolah tersebut diserahkan sepenuhnya kepada Y.B Mangunwijaya dan Yayasan Dinamika Edukasi Dasar (DED) (Ramopolo, 2020).

Rencana untuk mendirikan sekolah juga mendapat dukungan dari oleh PT Gramedia Widiasarana Indonesia dalam bentuk kerjasama pelaksanaan pendidikan di SD Kanisius Mangunan pada tahun 1994. Dukungan juga datang dari Departemen Pendidikan dan Kebudayaan (Depdikbud) dengan memberikan izin operasional secara resmi. Setelah melalui berbagai proses, akhirnya sekolah dasar Eksperimental di Mangunan resmi berdiri. Segala kebutuhan pendanaan dibiayai oleh Y.B. Mangunwijaya dari hasil royalti buku-buku yang diterbitkan. Sekolah Dasar Eksperimental Mangunan didesain sesuai dengan cita-cita Y.B Mangunwijaya yaitu dengan konsep pendidikan yang memerdekakan dan memperhatikan kebutuhan anak-anak miskin. Konsep-konsep pendidikan yang dimiliki oleh Y.B Mangunwijaya diaplikasikan dalam proses pembelajaran di sekolah tersebut. Suasana yang dibangun Y.B. Mangunwijaya di SD Eksperimental Mangunan tidak lagi berfokus pada kompetisi anak, namun lebih pada jiwa kesetiakawanan antara murid yang cerdas dan lambat. Sehingga antara muridmurid tersebut terjadi kerjasama serta tidak saling mementingkan kemajuan dirinya sendiri (Ramopolo, 2020)

Visi SD Eksperimental Mangunan yaitu terwujudnya komunitas pemelajar yang berjiwa eksplorati, kreatif, dan integral. Sedangkan misinya: mewujudkan siswa yang eksploratif kreatif dan integral melalui perkembangan/memekarkan tujuh modal dasar anak, mewujudkan guru yang inovatif pelopor eksploratif, mewujudkan suasana sekolah yang merdeka berkreasi. SD Eksperimental Mangunan juga menetapkan profil anak yang eksploratif, kreatif dan integral, antara lain: 1) Anak yang mampu memahami esensi dari materi pembelajaran. 2) Mampu belajar dari keluarga dan masyarakat. 3) Mampu 
bekerjasama dengan pribadi atau kelompok untuk mencari sumber belajar alternatif. 4) Anak terlibat aktif dalam pembelajaran. 5) Anak mampu menemukan ide dan mengkomunikasikan. 6) Anak mampu menerapkan hasil belajarnya dikeluarga dan masyarakat. 7) Anak mampu menemukan gagasan dari proses yang dialami. 8) Anak mempertanggungjawabkan gagasan dan kreasi yang ditemukan. 9) Anak mampu memaknai pengalaman belajarnya.

Cara mewujudkan visi dan misi tersebut dengan melakukan hal berikut: 1) materi generatif yaitu materi pembelajaran yang disampaikan kepada siswa dapat menumbuhkan rasa heran kagum dan bertanya atau menimbulkan rasa keingintahuan siswa yang lebih lagi, menimbulkan ide-ide baru dan dan pengetahuan baru. 2) Aktif, yaitu karena rasa ingin tahu anak-anak aktif untuk mencari tahu dengan menggali beberapa sumber melalui aktivitas bertanya dan percobaan. 3) Berdaya guna (metakognisi) yaitu melihat kembali apakah proses belajar anak bermanfaat bagi kehidupan sekitarnya (integral), anak mampu berefleksi. 4) Kerjasama yaitu terjalin kerjasama di komunitas pelajar untuk saling membantu antara siswa dengan siswa, guru dengan siswa, dengan orangtua siswa, dan juga dengan masyarakat. 5) Passion, yaitu siswa memiliki minat terhadap sesuatu sehingga siswa mau mengembangkan dirinya berdasarkan minat tersebut. 6) Budaya, terciptanya budaya sekolah, kebiasaankebiasaan yang dilakukan oleh siswa-siswa, tidak lagi harus disuruh tetapi sudah menjadi kesadaran di dalam diri siswa. Nilai-nilai yang ada di sekolah berjalan secara alami tanpa harus dipaksakan sebagaimana sebuah komunitas. Berikut Pelaksanaan Pendidikan Humanis di Sekolah Dasar Eksperimental Mangunan:

\section{Menjadikan Sekolah Sebagai Komunitas Pembelajar}

Sekolah Dasar Eksperimental Mangunan menjadikan sekolah sebagai komunitas pemelajar. Kata pemelajar dipakai atau digunakan karena menurut pedoman umum ejaan bahasa Indonesia, kata pemelajar diartikan sebagai orang yang belajar. Sedangkan kata pembelajar memiliki arti orang yang mengajar. Maka dari itu, Sekolah Dasar Eksperimental Mangunan menggunakan kata pemelajar dan bukan pembelajar. Konsep yang diusung SD Eksperimental Mangunan adalah menjadikan sekolah sebagai komunitas pemelajar. Layaknya sebuah komunitas maka anggota di dalamnya dipersepsikan memiliki berbagai latar belakang yang berbeda-beda seperti perbedaan budaya, kelas sosial, kemampuan yang dimiliki, mimpi yang dicita-citakan, dan lain sebagainya tapi disatukan dengan nilai-nilai yang sama (Orden c, 1960). Dengan perbedaan yang ada dalam komunitas pemelajar tersebut maka anggota komunitas diharapkan bisa saling belajar antara anggota satu dengan yang lainnya, baik antara siswa dengan guru, siswa dengan siswa, guru dengan guru, guru dengan orang tua siswa, dan lain sebagainya. Tercipta suasanya yang kolaborasi sesama anggota komunitas. SD Eksperimental Mangunan mencoba menjadikan suasana sekolah tidak berbeda dengan situasi dalam sebuah masyarakat. Sekolah adalah masyarakat dan sebaliknya masyarakat adalah sekolah. Hal ini seperti konsep pendidikan humanis menurut Rogers, salah satu ciri penting di dalam proses pembelajaran yang humanis adalah pembelajaran yang bermakna yaitu tidak terlepas dari konteks lingkungan yang ditinggali oleh anak-anak atau materi-materi yang disampaikan di sekolah merupakan materi-materi yang memiliki relevansi dengan kehidupan anak-anak (Sumantri \& Ahmad, 2019). 
Sekolah Dasar Eksperimental Mangunan menginginkan suasana sekolah tidak jauh berbeda dengan suasana sebuah komunitas dan suasana masyarakat. Anak-anak dibiasakan dalam suasana yang tidak homogen, karena anak-anak dipersepsikan tidak mungkin terus-menerus tumbuh dalam suasana yang dibuat sama. Pada kenyataannya anak-anak hidup dan tumbuh di dalam heterogenitas baik dari segi latar belakang budaya, agama, mimpi, keluarga dan lain-lain. Anak-anak adalah bagian dari masyarakat dan suatu hari nanti akan hidup di masyarakat. Maka sejak dini harus dibelajarkan tumbuh dan berkembang selayaknya dalam sebuah komunitas atau masyarakat. Oleh karena itu, sekolah disuasanakan layaknya kehidupan disebuah komunitas atau masyarakat. Sehingga anak-anak tumbuh, berkembang dan belajar secara alami sebagaimana dalam sebuah komunitas atau masyarakat. Sebagaimana pendapat Dewey bahwa salah satu cara untuk mencapai tujuan pendidikan humanis yaitu proses pembelajaran mesti didasarkan pada pengalaman hidup yang faktual dan aktual anak (Dewey, 2008). Hal lain yang penting dan tidak boleh diabaikan adalah terciptanya komunikasi yang baik sesama anggota komunitas agar terjadi saling kerja sama di dalamnya (McCloskey et al., 2011).

Di SD Eksperimental Mangunan untuk mewujudkan komunitas pemelajar yang eksploratif, keatif, dan integral. Maka terdapat enam komponen yang mesti dihadirkan dalam komunitas pemelajar agar tujuan komunitas pemelajar dapat terwujud dengan baik. Komponen yang pertama untuk dihadirkan di dalam komunitas pemelajar adalah bagaimana materi-materi yang disusun adalah materi-materi yang generatif. Artinya materi-materi tersebut dapat menimbulkan rasa kagum dan heran. Dari perasaan kagum dan heran maka anak-anak bertanya atas dasar keheranan dan kekaguman tersebut. Selanjutnya diharapkan untuk menjawab rasa keingintahuannya maka anak-anak atau siswa-siswa mencoba mencari jawaban atas pertanyaan-pertanyaannya tersebut. Anakanak diharapkan melakukan kegiatan eksploratif guna mencari jawaban atas pertanyaan pertanyaan mereka sendiri.

Komponen komunitas pembelajar yang kedua adalah mendorong anak menjadi pelaku pembelajaran yang aktif. Anak-anak didorong untuk mencari pengetahuanpengetahuan yang yang timbul dari perasaan kagum, heran, lalu bertanya. Untuk menemukan jawaban pertanyaan tersebut anak-anak didorong untuk mencoba menemukan sendiri jawaban-jawaban. Jadi guru tidak langsung memberikan jawaban begitu saja tetapi memancing atau mendorong supaya siswa mencari sendiri pengetahuan. Komponen yang ketiga adalah metakognisi atau berdaya guna, kemampuan metakognisi adalah kemampuan untuk merefleksikan atau memaknai segala sesuatu, karena salah satu hal utama dari proses pendidikan humanis adalah kemampuan untuk berefleksi atau memaknai dari pengalaman yang didapatkan siswa (Min Aung, 2020). Dari proses memaknai tersebut maka akan memunculkan pengetahuan-pengetahuan baru atau sikap-sikap yang semestinya harus dilakukan. Sebagai contoh ketika seorang guru dan siswa melakukan sebuah pembelajaran proyek maka guru dan siswa tersebut mencoba merefleksikan dari apa yang yang telah dilakukan.

Komponen yang keempat adalah adanya saling kerjasama yang dilakukan oleh anggota-anggota komunitas. Pembiasaan-pembiasaan ini dilakukan melalui pembelajaran-pembelajaran berbasis proyek. Harapannya ketika anak-anak menyelesaikan proyek tertentu atau sebuah kegiatan pembelajaran tertentu, anak-anak mencoba untuk menjalin kerjasama dengan pihak lainnya, baik dengan gurunya, orang 
tuanya, teman-temannya, saudaranya atau juga bahkan dengan masyarakat. Semangat yang diharapkan dari adanya kerjasama ini adalah semangat untuk saling memberi inspirasi, saling mengisi kekurangan yang yang dimiliki antara anggota komunitas yang satu dengan yang lainnya. Jadi bukan untuk kompetisi namun lebih ditekankan adalah kemampuan untuk saling bekerja sama antara satu dengan yang lainnya. Komponen yang kelima adalah munculnya passion atau minat anak terhadap sesuatu, dan guru membacanya dari aktivitas keseharian yang dilakukan oleh anak-anak saat melakukan proses pembelajaran melalui kegiatan proyek. Setelah diketahui passion serta kecenderungan bakat anak terhadap suatu hal maka guru mendorong untuk terus mengembangkan apa yang menjadi bakat atau passion tersebut.

Komponen yang keenam adalah adanya budaya sekolah yang menjadi pegangan dan dihidupi oleh seluruh anggota komunitas pemelajar. Setelah nilai-nilai terbentuk dari proses kagum, heran, dan bertanya lalu kemudian mencari jawaban atas pertanyaan. Selanjutnya terjadi kerjasama dan refleksi atas apa yang dilakukan dalam proses pembelajaran. Dari situ diharapkan muncul bakat atau minat dari siswa atau anak-anak di SD Eksperimental Mangunan. Diharapkan kegiatan berjalan dengan alami natural sehingga terbentuklah budaya sekolah yang eksploratif, kreatif, dan integral. Dalam komunitas pemelajar nilai atau budaya sekolah merupakan hal yang penting untuk dijadikan pijakan bagi seluruh anggota komunitas. Nilai-nilai itu harus terus hidup dan dikembangkan secara terus-menerus dalam komunitas pemelajar, nilai-nilai itu adalah eksploratif, kreatif, dan integral serta harus menjadi pegangan bersama untuk hidup bersama di dalam komunitas pemelajar

Tujuan dari komunitas pemelajar adalah sebagaimana yang tercantum dalam visi SD Eksperimental Mangunan yaitu terciptanya komunitas pemelajar yang berjiwa eksploratif, kreatif, dan integral. Untuk mencapai tujuan tersebut maka segala aktifitas baik nilai-nilai yang dipegang, suasana yang dihadirkan adalah untuk mendorong siswa atau anak-anak, dan anggota komunitas lainnya memiliki kemampuan untuk bereksplorasi, kreativitas, dan integral. Guna mencapai hal tersebut maka SD

Eksperimental Mangunan mendesain kurikulum organis yang dapat mendorong terbentuknya anggota komunitas pembelajar khususnya siswa supaya memiliki jiwa yang eksploratif, kreatif, dan integral.

\section{Tujuh Modal Dasar Anak}

Anak-anak adalah pribadi yang memiliki potensi dalam dirinya. Bukan seperti sebuah kertas kosong yang diisi semua-maunya oleh guru-gurunya. Tugas sekolah adalah mengembangkan potensi yang sudah ada di dalam diri anak. SD Eksperimental Mangunan memandang anak-anak memiliki potensi di dalam dirinya dan potensi itu perlu didorong untuk bisa berkembang. SD Eksperimental Mangunan menamakan potensi-potensi yang ada dalam diri anak sebagai tujuh modal dasar anak yang mesti dikembangkan atau dimekarkan. Ketujuh modal dasar tersebut adalah pertama model karakter, kedua modal bahasa, ketiga modal orientasi diri, keempat modal logika kuantitatif, kelima modal pengenalan piranti dan alat, keenam adalah model kerjasama dan yang ketujuh adalah olahraga. Pandangan terkait adanya potensi dalam diri siswa senada dengan Maslow, yang mengatakan bahwa manusia memiliki potensi-potensi dalam dirinya yang mesti diaktualisasikan (Firdaus \& Mariyat, 2017)

Modal karakter merupakan modal yang mendasar dan vital karena mencakup sikap ketakwaan, mental, dan spiritual. Karakter ini mengisi jiwa dari pengetahuan yang 
memiliki sifat netral. Karakter akan membawa kemana arah tujuan pengetahuan tersebut dimanfaatkan. Modal penguasaan bahasa mencakup kemampuan menggunakan bahasa nasional dan bahasa asing, hal ini penting karena untuk mengakses berbagai informasi dan pengetahuan. Dengan menguasai bahasa diharapkan anak-anak mampu untuk memajukan diri dan beradaptasi dengan segala perubahan zaman yang terjadi begitu cepat terutama dizaman globalisasi saat ini.

Modal orientasi diri adalah anak mengenal dirinya, dengan mengenal pada dirinya sendiri siswa atau anak-anak mengerti apa yang mesti dilakukannya, memiliki arah dan tujuan sehingga tidak dibingungkan oleh kemajuan zaman. Dengan memiliki orientasi diri anak-anak menjadi tahu apa yang harus mereka lakukan. Logika kuantitatif merupakan kemampuan untuk berpikir logis mampu berpikir dengan nalar. Sehingga anak-anak ketika melakukan sesuatu akan penuh perhitungan karena telah melalui refleksi dan berfikir logis.

Mengenal dunia perkakas piranti atau alat fisik merupakan kemampuan untuk mengenal berbagai macam benda di dunia ini dan hukum-hukumnya serta mampu memanfaatkannya dalam kehidupan sehari-hari serta mengetahui bagaimana cara menjaganya. Belajar kerjasama merupakan kemampuan untuk melakukan kerjasama, membentuk tim, dan berorganisasi. Diharapkan siswa atau anak-anak saling mengisi kekurangan satu dengan yang lain melalui kerjasama. Modal olahraga, diharapkan anak-anak memiliki tubuh yang sehat dan membuat jiwanya menjadi kuat. Dengan mekarnya tujuh modal dasar yang dimiliki anak, harapannya jiwa yang eksploratif, kreatif, dan integral dapat terwujud. Pada setiap anak memiliki motivasi untuk mengaktulisasikan potensi yang ada pada dirinya (Anjanaben \& Mehta, 2019). Untuk itu seluruh kegiatan pembelajaran di SD Eksperimental Mangunan adalah aktivitas-aktivitas yang mendorong untuk mengembangkan ketujuh modal dasar yang dimiliki siswa.

\section{Kurikulum Organis Pohon Kurikulum Mangunwijaya}

Kurikulum Sekolah Dasar Eksperimental Mangunan mengacu pada kurikulum yang telah ditetapkan oleh pemerintah, namun dilakukan modifikasi atau penyesuaian dengan kondisi dan kebutuhan saat ini. Sebagai contoh tema pembelajaran yang yang digunakan tidak mesti sama dengan yang yang ada di buku paket pemerintah, tetapi tema dan sub tema disesuaikan dengan kondisi dan keadaan lingkungan sekitar. Tema dan subtema akan berubah disetiap pergantian tahun ajaran

Kurikulum merupakan hal penting untuk memekarkan tujuh modal dasar yang dimiliki oleh anak-anak supaya dapat terwujud jiwa yang eksploratif, kreatif, dan integral. Sekolah Dasar Eksperimental Mangunan memandang kurikulum bukanlah sekedar perangkat pembelajaran, tetapi kurikulum merupakan sebuah ekosistem yang menyeluruh. Kurikulum yang digunakan di SD Eksperimental Mangunan dinamakan pohon kurikulum Mangunwijaya. Sebagaimana sebuah pohon maka untuk bisa tumbuh dan berkembang dengan baik maka diperlukan kondisi alam yang mendukung, untuk itu kurikulum ini diibaratkan sebagai sebuah ekosistem yang saling mendukung seluruh komponennya. Untuk mendukung hal tersebut maka kurikulum SD Eksperimental Mangunan dibuat secara organik yaitu materi pelajaran akan saling mendukung mata pelajaran- mata pelajaran yang lainnya, jadi tidak saling terpisah-pisah. Pohon kurikulum Mangunwijaya dapat dilihat pada gambar 1.

Dari gambar pohon kurikulum Mangunwijaya di atas diketahui bahwa pohon kurikulum Mangunwijaya memiliki tiga komponen dasar yaitu bagian akar, batang, daun, 
bunga dan buah. Di bagian akar adalah komponen sikap, karakter serta identitas dan orientasi diri. Mata pelajaran yang terdapat dibagian akar merupakan yang dianggap untuk membentuk karakter identitas dan orientasi diri siswa yaitu mencakup IImu Pengetahuan Sosial, Bahasa, Pendidikan Pancasila dan Kewarganegaraan

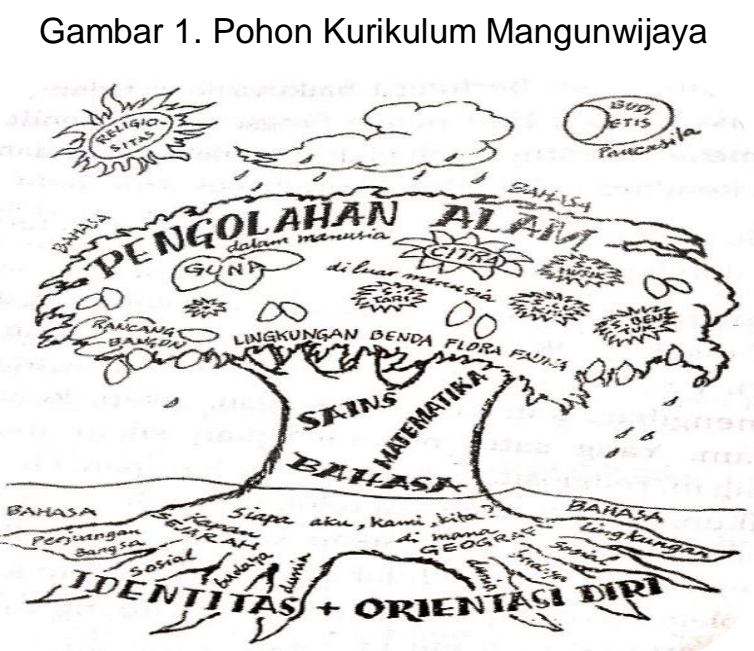

(Sumber, Mangunwijaya, 2020:94)

Dari gambar pohon kurikulum Mangunwijaya di atas diketahui bahwa pohon kurikulum Mangunwijaya memiliki tiga komponen dasar yaitu bagian akar, batang, daun, bunga dan buah. Di bagian akar adalah komponen sikap, karakter serta identitas dan orientasi diri. Mata pelajaran yang terdapat dibagian akar merupakan yang dianggap untuk membentuk karakter identitas dan orientasi diri siswa yaitu mencakup IImu Pengetahuan Sosial, Bahasa, Pendidikan Pancasila dan Kewarganegaraan. Identitas diri dimaksudkan supaya anak bisa memahami siapa dirinya, mengenal siapa dirinya, seperti di mana saya tinggal, dengan siapa saya tinggal, dan bagaimana kondisi saya dan lingkungan saya. Dengan mengenali hal-hal tersebut maka diharapkan anak akan tahu dan mengerti apa yang mesti diperbuatnya. Selanjutnya pada bagian batang adalah kemampuan berpikir logis atau kemampuan untuk bernalar, mata pelajaran yang dikembangkan untuk mendorong kemampuan berpikir logis dan bernalar ini adalah Matematika, Bahasa, dan Sains atau Ilmu Pengetahuan Alam.

Sedangkan pada bagian bagian daun, bunga, dan buah adalah keterampilan yang disana ada guna dan citra. Mata pelajaran untuk mendukung kemampuan siswa ini adalah ekstra kurikuler, dan olahraga. Kesemua mata pelajaran tadi merupakan sarana untuk memekarkan tujuh modal dasar anak yaitu karakter yang letaknya di akar. Bahasa yang ada di semua bagian pohon, menyemangati seluruh pembelajaran. Orientasi diri yang letaknya di akar. Logika kuantitatif yang letaknya di batang. Pengenalan piranti yang letaknya antara daun dan batang, kemudian kerjasama yang ada di seluruh pohon. Olahraga yang ada di daun, bunga, dan buah. Keseluruhan pohon kurikulum ini akan bisa tumbuh dan berkembang dengan baik jika kondisi alamnya juga mendukung untuk pohon bisa tumbuh dan berkembang. Pada bagian alam terdapat religiusitas, budi etis, dan nilai Pancasila, dan nilai-nilai yang lain.

\section{Tugas Guru Menemani Belajar Anak}


Komunikasi dengan hati maka akan menimbulkan suasana empati. Istilah dari Mangunwijaya yaitu meletakan hati. Sedangkan komunikasi secara egaliter atau demokratis akan memberikan ruang bagi siswa-siswa untuk tumbuh dan mekar secara maksimal. Dalam komunitas pemelajar guru bukanlah satu-satunya sumber belajar, namun sumber belajar dari berbagai macam hal, baik yang terdapat di sekolah, rumah, ataupun masyarakat. Guru hanya berperan sebagai pendamping yang mendorong anakanak atau siswa siswa mengembangkan potensi yang ada di dalam dirinya. Harapanya anak melakukan eksplorasi secara mandiri guna menemukan pengetahuan. Guru tidak menjadi satu-satunya sumber belajar sehingga proses pendidikan membebaskan dan tidak bergaya bank (Freire, 1999). Anak diberikan suasana demokratis dalam proses belajar, supaya memiliki kebebasan dalam mengembangkan potensi yang dimiliki anak (Sant, 2019). Selain anak diminta untuk mampu mengembangkan dirinya, guru juga dituntut untuk mimiliki keberanian menghadapi kebebasan anak didiknya, memiliki keterbukaan terhadap ide-ide baru dari anak-anak, fleksibel dalam meramu proses pembelajaran serta memberi apresiasi kepada siswa atas kinerja yang dilakukan dalam usaha menemukan pengetahuan (Willers, 2009, p. 43)

\section{Pembelajaran Khas}

Guna memekarkan tujuh model dasar yang dimiliki anak, maka SD Eksperimental Mangunan menyusun kurikulum yang di dalamnya terdapat beberapa mata pelajaran wajib sebagaimana yang ditetapkan pemerintah, namun selain praktekpraktek pelajaran di kelas ditambah ekstrakurikuler yang mencakup kepramukaan bahasa Inggris dan juga teknologi informasi. Terdapat juga beberapa kelas ekspresi yang bisa diikuti oleh siswa-siswa di SD Eksperimental Mangunan. Ditambah ada pembelajaran yang menjadi khas di SD Eksperimental Mangunan. Pembelajaran khas ini tidak masuk dalam struktur kurikulum namun bisa dikatakan sebagai yang menjiwai dan menjadi iklim proses pembelajaran. Pembelajaran khas meliputi komunikasi iman, membaca buku bagus, koper (kotak pertanyaan), musik pendidikan, dan literasi.

Komunikasi iman merupakan cara bagaimana memperkenalkan anak-anak atau siswa-siswa untuk mengenal Tuhannya, tetapi proses yang dilakukan adalah dengan cara-cara melakukan refleksi terhadap apa yang ditemui oleh siswa. Seperti halnya ketika kita melihat keindahan atau fenomena alam tertentu maka pengalaman tersebut direfleksikan bahwa keindahan dan fenomena alam yang terjadi itu karena adanya kehendak Tuhan Yang Maha Esa. Diharapkan dengan adanya komunikasi iman yang diselipkan dalam setiap proses pembelajaran maka anak-anak berkembang ketakwaan dan dan akhlak mulianya.

Membaca buku bagus adalah aktivitas yang dilakukan oleh anak-anak dengan membaca kisah-kisah tokoh yang bisa memberikan inspirasi. Dengan membaca kisah atau cerita tentang perjalanan hidup seseorang maka anak-anak mampu merefleksikan apa yang dia baca sehingga menjadi pengalaman untuk mengenal dirinya serta akan mendapat inspirasi untuk melakukan sesuatu dimasa yang akan datang.

Pembelajaran khas kotak pertanyaan (koper), kegiatan kotak pertanyaan memberikan anak-anak kebebasan untuk bertanya tentang apapun. Karena kebebasan, keadilan dan kesetaraan merupakan nilai-nilai dari pendidikan humanis (Setiawan \& Ardianto, 2018). Harapannya jawaban dari pertanyaan tersebut ditemukan oleh siswasiswa sendiri melalui kerjasama dengan siswa yang lain atau dengan gurunya. Tugas guru memancing dengan materi-materi yang generatif sehingga anak-anak timbul rasa 
kagum heran dan muncul keingintahuan lebih banyak sehingga anak-anak akan bertanya tentang apa yang ingin diketahui.

Pembelajaran khas selanjutnya adalah musik pendidikan, musik pendidikan ini diharapkan anak merasakan irama, dengan merasakan irama, anak akan mengetahui bahwa di dalam hidup ini terdapat pola-pola tertentu yang perlu kita sadari. Pembelajaran khas selanjutnya adalah literasi. Pengembangan literasi dimaknai sebagai proses belajar atau orang yang belajar mulai dari rasa kagum heran dan bertanya ingin tahu dan mencari tahu jawaban sampai pada mengapresiasikan ilmu pengetahuan maka program literasi tidak hanya membaca tetapi dari bacaan itu bagaimana anak-anak mengekspresikan pengetahuan atau pengalaman tadi dalam bentuk proyek seperti, buku, puisi, dan cerita-cerita. Untuk menunjang itu selain berkunjung ke perpustakaan, anak melakukan aktivitas membaca hening 15 menit sebelum dimulainya pembelajaran setiap pagi. Pembelajaran khas di atas yang meliputi komunikasi iman, membaca buku bagus, musik pendidikan, literasi diharapkan semakin mendorong anak-anak untuk memiliki jiwa yang eksploratif, kreatif dan integral.

Selain itu, Sekolah Dasar Eksperimental Mangunan juga mendorong beberapa pembiasaan guna mendukung dan mempercepat pemekaran tujuh modal dasar yang dimiliki oleh siswa. Pembiasaan tersebut antara lain: upacara bendera setiap hari Senin, senam bersama seminggu sekali, pendidikan lingkungan hidup seperti merawat tanaman, mencuci tangan, 7S, pagi berjabat, berpakaian sopan dan rapi, mengucapkan kata tolong, maaf dan terimakasih, bakti sosial, peringkatan hari besar, penanaman budaya keteladanan, budaya hidup bersih dan sehat, budaya antri dan budaya sosial.

\section{Model Pembelajaran Berbasis Proyek}

Salah satu strategi yang digunakan untuk menumbuhkan dan mengembangkan tujuh modal dasar yang dimiliki anak serta untuk mewujudkan komunitas pemelajar yang berjiwa eksploratif, kreatif, dan integral maka model pembelajaran yang digunakan di SD Eksperimental Mangunan yaitu dengan menggunakan model pembelajaran yang berbasis proyek. Dengan menggunakan pembelajaran berbasis proyek maka dimungkinkan anak-anak akan melakukan sebuah pengamatan kemudian percobaan untuk menemukan pengetahuan, lalu mempresentasikan pengalamannya yang didapat dari proses eksplorasi.

Selanjutnya teknik penilaian yang digunakan di Sekolah Dasar Eksperimental Mangunan adalah menggunakan penilaian yang autentik atau penilaian proses, yaitu tidak hanya dilakukan penilaian diakhir program pembelajaran tetapi selama proses pembelajaran tersebut anak-anak dilakukan penilaian secara berkala. Oleh karena itu, terkadang diakhir semester tidak ada ulangan atau tes. Hal tersebut dikarenakan penilaian dilakukan disepanjang semester dengan penilaian proses. Dan selama proses pembelajaran anak-anak diberikan kemerdekaan untuk melakukan eksplorasi untuk menemukan pengetahuannya sendiri, anak-anak didoroang untuk nggiwar (berfikir out of the box). Sebagaimana menurut Wiley, bahwa humanisme adalah sikap hidup yang demokratis dan etis, yang menegaskan bahwa manusia memiliki hak dan tanggung jawab untuk menemukan serta memberi makna pada dirinya sendiri berdasarkan nilainilai kemanusiaan (Wiley, 2015). Hal tersebut mendorong terciptanya tujuan pendidikan humanistik yaitu berkembangnya pribadi yang bebas untuk menentukan nasibnya 
sendiri, selalu memperbaruhi diri dan teraktualisasinya potensi-potensi yang ada dalam dirinya (Willers, 2009).

Pada intinya, kurikulum Sekolah Dasar Eksperimental Mangunan mengacu pada kurikulum yang telah ditetapkan oleh pemerintah, namun dilakukan modifikasi atau penyesuaian dengan kondisi dan kebutuhan saat ini. Sebagai contoh tema pembelajaran yang yang digunakan tidak mesti sama dengan yang yang ada di buku paket pemerintah, tetapi tema dan sub tema disesuaikan dengan kondisi dan keadaan lingkungan sekitar. Tema dan subtema akan berubah disetiap pergantian tahun ajaran. Dalam perjalanannya terdapat hambatan yang ditemui dalam prosesnya salah satunya yaitu belum populernya model pendidikan humanis di Indonesia, sehingga muncul banyak pertanyaan dari orang tua siswa yang belum memahami model pembelajaran yang digunakan di sekolah. Selain itu, pendidikan humanis memerlukan waktu pembelajaran yang lebih lama, karena pengetahuan tidak langsung diberikan oleh guru, namun sebisa mungkin ditemukan oleh anak. Padahal kompetensi yang mesti dikuasai tidaklah sedikit. Oleh karena itu, harus ada solusi yang mesti diambil guna menyelesaikan permasalahan tersebut. Diantaranya perlunya sosialisasi terkait penerapanan model pembelajaran humanis kepada wali murid dan juga siswa. Persyaratan kompetensi minimal yang mesti dicapai dilakukan penyederhanaan, disesuaikan dengan kebutuhan siswa.

\section{KESIMPULAN}

Pelaksanaan pendidikan di Sekolah Dasar Eksperimental Mangunan telah mengusung pendidikan humanis demokratis yang nampak dari hal-hal berikut: Sekolah Dasar Ekperimental Mangunan memandang bahwa setiap siswa memikili potensi yang dikenal dengan tujuh modal dasar, diterapkannya pendidikan yang memerdekakan siswa, mengaplikasikan pembelajaran yang bermakna, penggunaan pendekatan pembelajaran yang berpusat pada siswa. Penelitian ini memberikan implikasi yaitu, setelah selesai melalui proses pendidikan anak-anak diharapkan mampu menyelesaikan masalah-masalah yang dihadapi dengan kemampuan eksplorasi yang dimilikinya, menumbuhkan jiwa yang mandiri pada anak sehingga tidak mudah tergantung kepada orang lain, potensi-potensi yang dimiliki oleh siswa/ anak mampu dikembangkan dan dapat tumbuh dengan baik.

\section{DAFTAR PUSTAKA}

Al-Hamdi, R. (2017). Ketika Sekolah Menjadi Penjara: Membongkar Dilema Pendidikan Masyarakat Modern. The Journal of Society \& Media, 1(1). https://doi.org/10.26740/jsm.v1n1.p11-34

Anjanaben, T., \& Mehta, A. (2019). Maslow's Hierarchy of Needs-Theory of Human Motivation. International Journal of Research in All Subjects in Multi Languages, $7(6)$.

Aruma, E. O., \& Enwuvesi Hanachor, M. (2017). Abraham Maslow's Hierarchy Of Needs And Assessment Of Needs In Community Development. International Journal of Development and Economic Sustainability, 5(7).

Darmaningtiyas. (2012). Pendidikan Yang Memiskinkan. Instrans Publising.

Dewey, J. (2008). Experience and education. Educational Forum, 50(3). https://doi.org/10.1080/00131728609335764

Fakih, M. (2010). Jalan Lain: Manifesto Intelektual Organik. Insist Press.

Firdaus, F. A., \& Mariyat, A. (2017). Humanistic Approach In Education According To Paulo Freire. At-Ta'dib, 12(2). http://dx.doi.org/10.21111/at-tadib.v12i2.1264 
Foucault, M. (1999). Disiplin Tubuh: Bengkel Individu Modern. LKIS.

Freire, P. (1999). Pendagogy Of The Opperesed. Indiana University Press.

Graham. (2005). Psikologi Humanistik dalam Konteks Sosial, Budaya Dan Sejarah. Pustaka Pelajar.

Hadi, H., Hafidhuddin, D., Husaini, A., \& Mujahidin, E. (2016). Kebijakan Pendidikan Nasional Terhadap Pendidikan Sekuler (Issue 2).

Indriatno, F. (2009). Pendagogi Humanisme Mangunwijaya. PT Kompas Media Nusantara.

Maiaweng, P. (2009). Analisis Konsep Pemikiran John Dewey.

Mangunwijaya. (2004). Pendidikan Pemerdekaan Separuh Perjalanan SDK Eksperimen Mangunan (Jatmiko). Dinamika Edukasi Dasar.

McCloskey, D. J., McDonald, M. A., \& Cook, J. (2011). Principles of Community Engagement.

Min Aung, Y. (2020). Humanism and Education. International Journal of Advanced Research in Science, Engineering and Technology, 7(5), 5-6.

Munirah. (2015). Sistem Pendidikan di Indonesia: antara keinginan dan realita. Jurnal Auladuna, 2(2), 233-245.

Orden c, S. (1960). What is a community?

Ramopolo, M. C. (2020). Pemerdekaan: Pendidikan dan Teologi Y.B. Mangunwijaya Menghadapi Revlusi Industri 4.0. PT. Kanisius.

Samawi. (1995). Konsep Demokrasi Dalam Pendidikan Menurut Progressivisme John Dewey.

Sant, E. (2019). Democratic Education: A Theoretical Review (2006-2017). Review of Educational Research, 89(5), 655-696. https://doi.org/10.3102/0034654319862493

Setiawan, A., \& Ardianto, D. T. (2018). The Innovation of Democratic Education: The Development of Learning Approach Based on the Sutan Syahrir' Thought to Strengthen Students' Democratic Attitude. Yupa: Historical Studies Journal, 2(2), 108-109.

Sumantri, B. A., \& Ahmad, N. (2019). Teori Belajar Humanistik dan Implikasinya Terhadap Pembelajaran Pendidikan Agama Islam. Jurnal Pendidikan Dasar, 3(2). https://doi.org/10.36088/fondatia.v3i2.216

Susetyo, B. (2005). Politik Pendidikan Penguasa. LKiS.

Wiley, J. (2015). The Wiley Blackwell Handbook of Humanism, First Edition. The Wiley Blackwell Handbook of Humanism, 6-7. https://doi.org/10.1002/9781118793305.ch1

Willers, J. C. (2009). Humanistic Education: Concepts, Criteria and Criticism. Peabody Journal of Education, 53(1), 39-44. https://doi.org/10.1080/01619567509538047 